\title{
A preliminary investigation into the ecology and behavior of blue whales (Balaenoptera musculus) in the Gulf of Corcovado, Chile
}

by

Alessandro Bocconcelli ${ }^{1}$, Leigh Hickmott ${ }^{2,3}$, Rafaela Landea Briones ${ }^{4}$,

Gloria Howes ${ }^{4}$ and Laela Sayigh ${ }^{1}$

September 2014

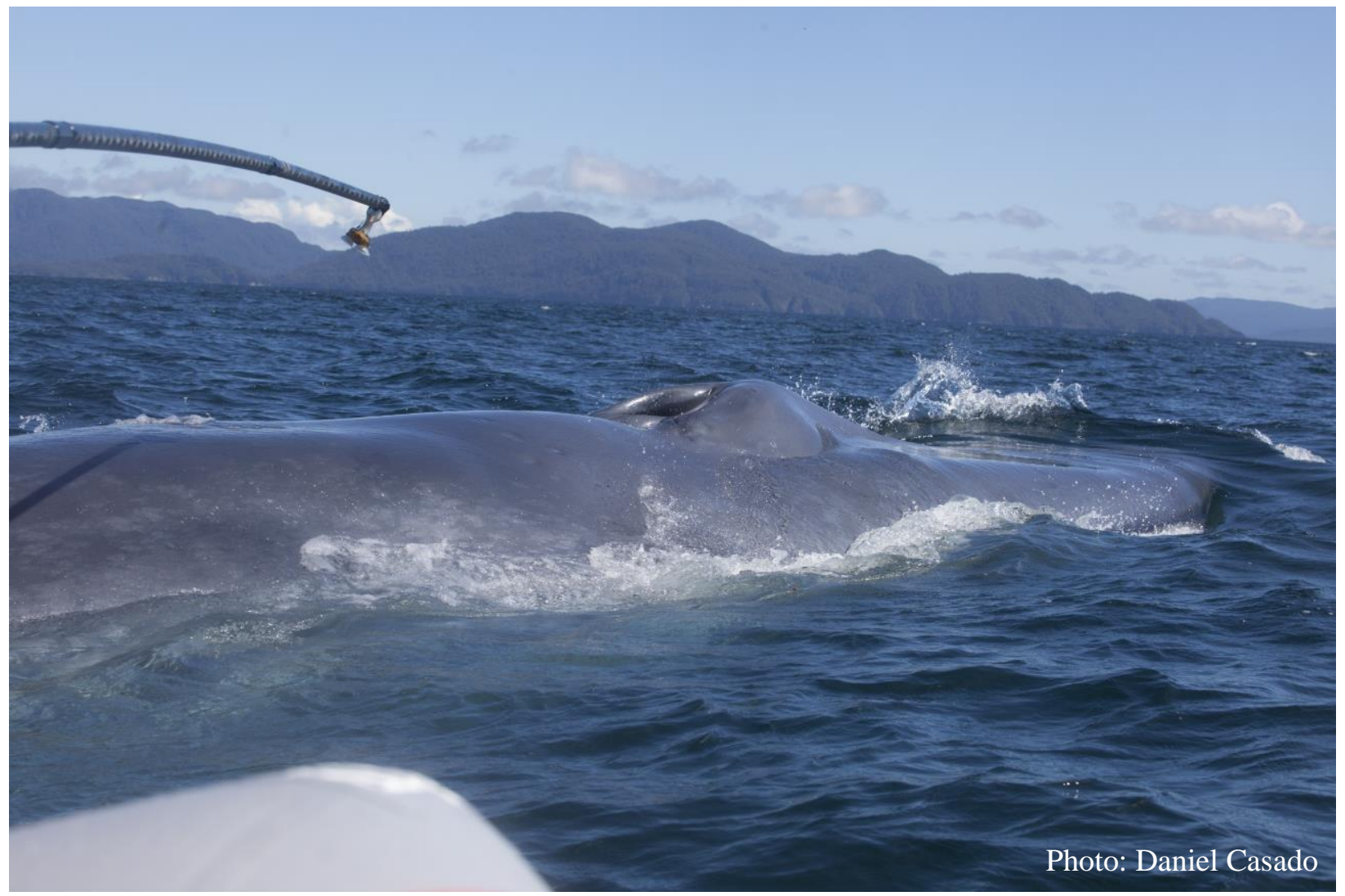

(1) Woods Hole Oceanographic Institution, 266 Woods Hole Road, Woods Hole, Massachusetts 02543-1050, USA. Email: abocconcelli@whoi.edu, 1sayigh@whoi.edu

(2) Open Ocean Consulting, 2 Borough House, 72 Borough Road, Petersfield, Hampshire, GU32 3LF, UK. Phone: +44 (0)1730 233231, email: leighhickmott@ theopenocean.co.uk

(3) Scottish Oceans Institute, East Sands, University of St Andrews, St Andrews, Fife, KY16 8LB, UK. Email: leighhickmott@st-andrews.ac.uk

(4) Centre MERI, 15.312.010-2 Av. Kennedy 5454, Of. 1002, Vitacura, Santiago, Chile. Email: rafaela@centromeri.cl, gloria@ centromeri.cl

\section{Technical Report}

Funding was provided by the Melimoyu Ecosystem Research Institute Approved for public release: distribution unlimited. 


\section{WHOI-2014-05}

\section{A Preliminary Investigation into the Ecology and Behavior of Blue Whales (Balaenoptera musculus) in the Gulf of Corcovado, Chile}

by

Alessandro Bocconcelli, Leigh Hickmott, Rafaela Landea Briones, Gloria Howes, and Laela Sayigh

Woods Hole Oceanographic Institution

Woods Hole, Massachusetts 02543

September 2014

\section{Technical Report}

Funding was provided by Melimoyu Ecosystem Research Institute

Reproduction in whole or in part is permitted for any purpose of the United States Government. This report should be cited as Woods Hole Oceanographic Institution Technical Report, WHOI-2014-05.

Approved for public release; distribution unlimited.

\section{Approved for Distribution:}

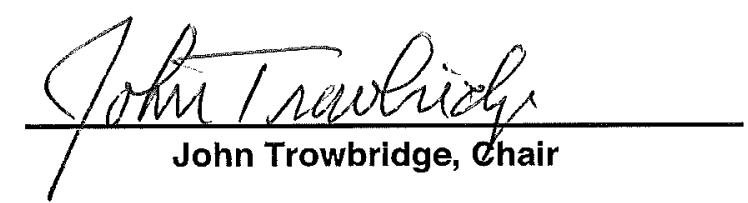

Department of Applied Ocean Physics and Engineering 



\begin{abstract}
A joint effort between WHOI and the Melimoyu Ecosystem Research Institute (MERI) sought to gain a better understanding of a population of blue whales (Balaenoptera musculus) in the Gulf of Corcovado, Chile. A cruise in March 2014 resulted in the deployment of 5 DTAGs, which are miniature sound and orientation recording tags that are attached via suction cups. A total of five tag deployments on four individual whales were achieved, totaling $21 \mathrm{hr} 11 \mathrm{~min}$. Dives were predominantly between 10 and $50 \mathrm{~m}$ in depth, with a maximum of $139 \mathrm{~m}$. Sloughed skin found on the suction cups of recovered tags and fecal samples were preserved to be used for genetic, dietary and pollutant analyses. Acoustic data on the tags revealed numerous calls from distant blue whales, and an apparent call exchange was recorded between a tagged juvenile whale and a distant animal. Photo-identification images and acoustic recordings of all marine mammal species encountered were obtained whenever possible; these included humpback whales (Megaptera novaeangliae), Peale's dolphins (Lagenorhynchus australis), Chilean dolphins (Cephalorhynchus eutropia), and bottlenose dolphins (Tursiops truncatus). Continuation of this collaboration has great potential to provide information to policy makers regarding how to protect the unique habitats in this region.
\end{abstract}




\section{Front Cover Figure Caption:}

Photograph of a suction-cup attached digital acoustic tag (DTAG) being deployed on a blue whale via a pole from a zodiac in the Gulf of Corcovado, Chile, in March 2014. Photograph taken by Daniel Casado under Chilean research permit: Ministerio de Economia, Fomento y Turismo, Subsecreteria de Pesca y Acuicultura, PINV 38-2014 Ballena Azul, Golfo Corcovado 


\section{Table of Contents}

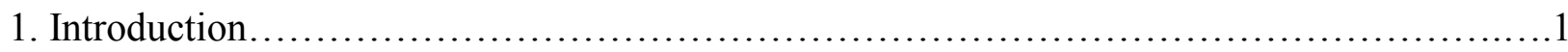

2. Project Personnel and Research Vessel...................................................

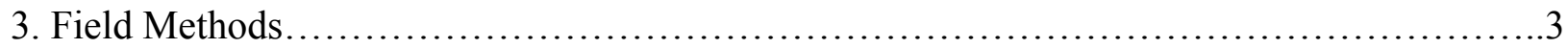

3.1 Tracking, visual data collection and photo-identification........................... 3

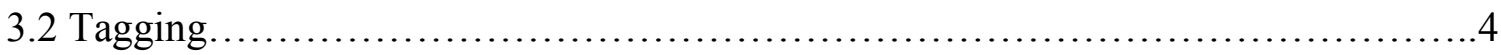

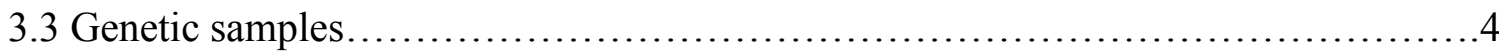

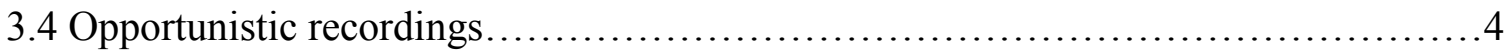

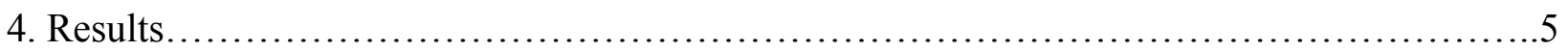

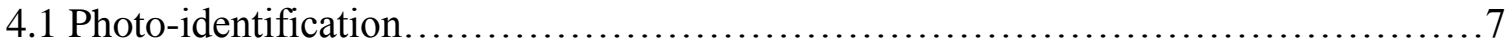

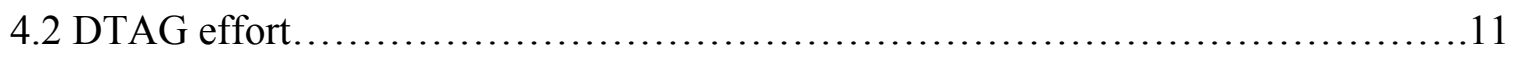

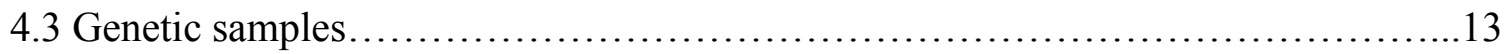

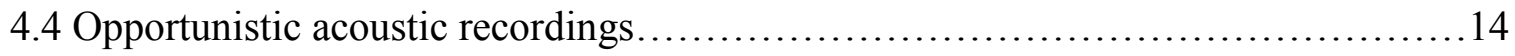

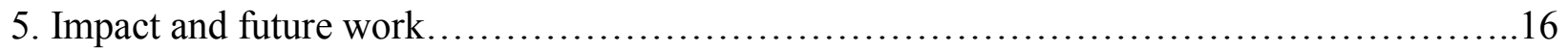

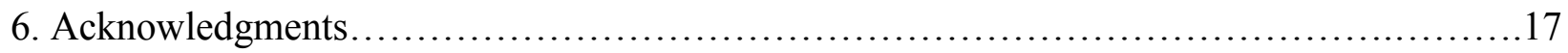

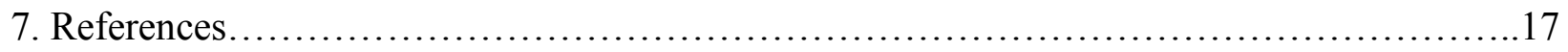

Appendix I. Instructions for blue whale behavioral data collection..........................20

\section{List of Figures}

Figure 1. Maps indicating the location of study region...........................................

Figure 2. Images of the DTAG and its attachment method..................................

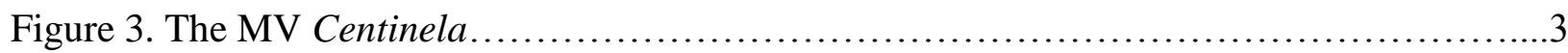

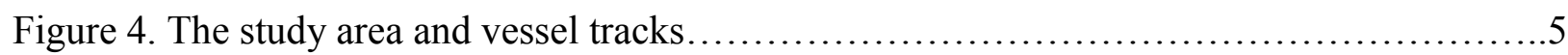

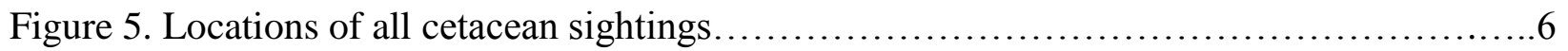

Figure 6. Photo-identification images of blue whales....................................... 8

Figure 7. Photo-identification images of humpback whales................................ 10

Figure 8. Dive profiles of four tagged blue whale.....................................12

Figure 9. Spectrograms of sounds recorded on tags of the presumed mother and juvenile........12

Figure 10. Spectrogram of bottlenose dolphin sounds.................................... 15

Figure 11. Spectrogram of Peale's dolphin sounds..........................................15

Figure 12. Spectrogram of Chilean dolphin sounds........................................ 16

Figure A1. Data sheet for behavioral observations of tagged whales..........................21

\section{List of Tables}

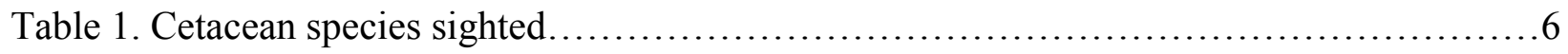

Table 2. Marine mammal species documented using photo-identification......................

Table 3. Blue whale encounter and photo-identification summaries......................... 7 
Table 4. Latitudes and longitudes of blue and humpback photo-identification locations..........9

Table 5. Humpback whale encounter and photo-identification summaries.....................10

Table 6. Blue whale DTAG deployment summaries.................................. 11

Table 7. Summary information for eight genetic samples .............................. 13

Table 8. Details regarding opportunistic acoustic recordings............................. 14 


\section{Introduction}

Blue whales are known principally by two contrasting accolades, firstly, as being the largest animal to have ever lived on Earth, and secondly, as having been hunted to near extinction during twentieth century whaling. During the whaling era over four thousand animals were caught in Chilean waters alone (Williams et al. 2011). The species has been slow to recover from almost total decimation and hence a valuable discovery was made in 1993, when a small blue whale population of 232 individuals was found in the Gulf of Corcovado in the Chiloense Ecoregion of Southern Chile (Hucke-Gaete et al. 2004). Genetic, acoustic and morphometric studies indicate that these blue whales are part of a wider Southeast Pacific population that is distinct from both the Antarctic (B. musculus intermedia) and "pygmy" (B. musculus brevicauda) blue whale subspecies (Branch et al. 2007, Buchan et al. 2014, Torres-Florez et al. 2014). Further investigations are required to establish the degree of isolation of the population and the health and viability of the individuals within it. Such knowledge is vitally important and will aid Chilean policy makers in generating informed management decisions regarding the conservation of this population.

This investigation set out to obtain data on the ecology, foraging and acoustic behavior of individual blue whales in and around the Gulf of Corcovado, Chile (Fig. 1), through the deployment of suction cup attached digital acoustic tags (DTAGs; Fig. 2). DTAGs are miniature sound and orientation recording tags developed at WHOI (Johnson and Tyack 2003). These tags contain a VHF transmitter used to track the tagged whale during deployment and to retrieve the tag after release. DTAGs record sound at the whale, as well as depth, and 3-dimensional acceleration and magnetometer information, and thus provide data on vocal, movement and dive behavior. The tag is attached with four suction cups using a hand-held $8 \mathrm{~m}$ carbon fiber pole (cover photo, Fig. 2), and can be programmed to release after durations of up to 24 hours. The aim was to achieve DTAG carries of several hours combined with visual tracking, radio tracking and photo-identification. A secondary aim was to complement and provide continuity to a previous MERI project involving passive acoustic monitoring of blue whales in the Gulf of Corcovado initiated in 2012 (Fig. 1). These combined efforts seek to better understand habitat use and establish abundance estimates in the study area. The month of March was chosen to conduct the field effort, based on historical blue whale sightings, acoustic detections and weather data. 


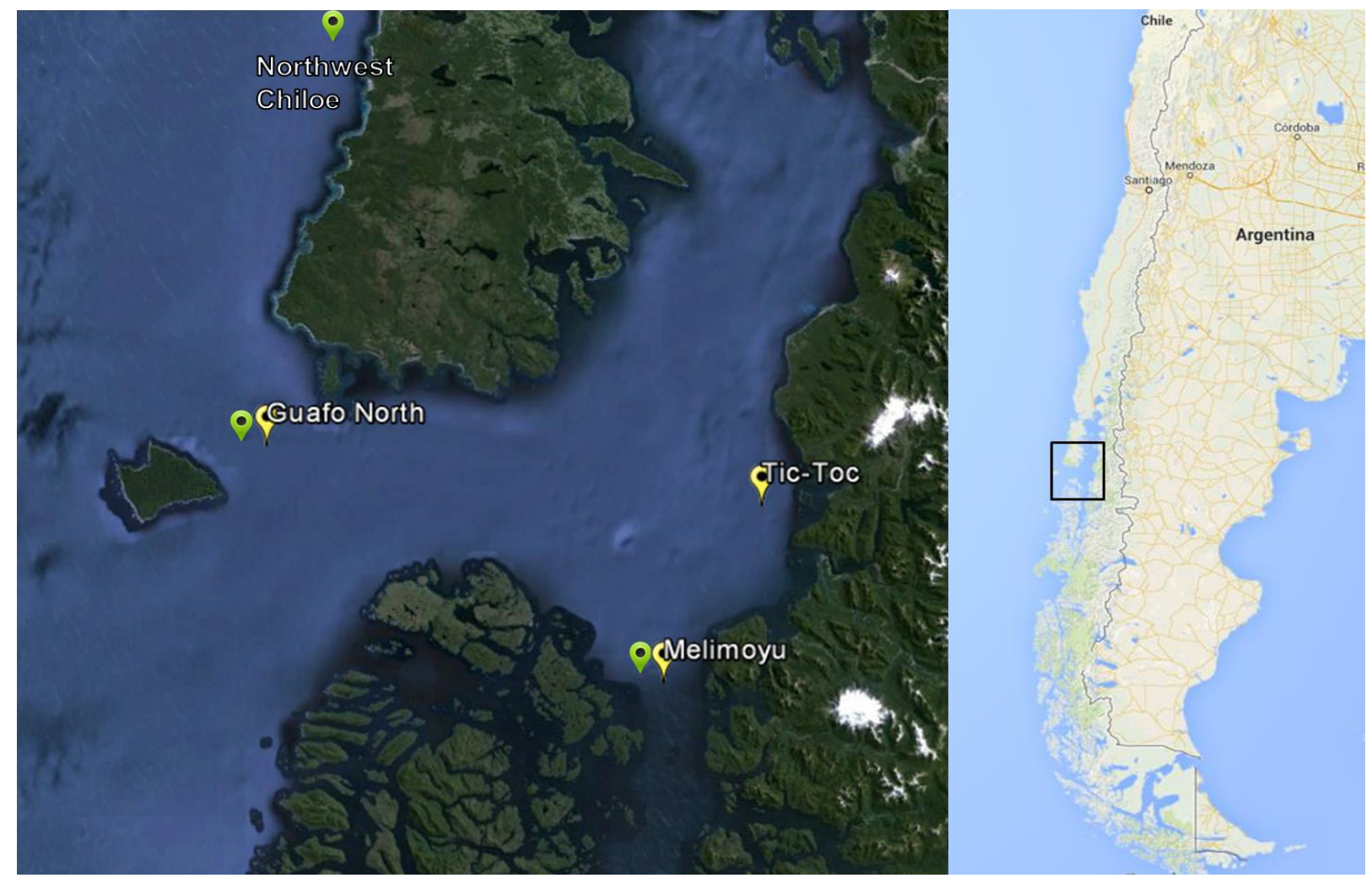

Figure 1. Maps indicating the location of study region on the coast of Chile (black box on the right) and an enlargement on the left, showing the locations of passive acoustic monitoring stations; these areas were considered the prime foraging areas in which to search for and detect blue whales in the Gulf of Corcovado (Hucke-Gaete and Buchan 2012)

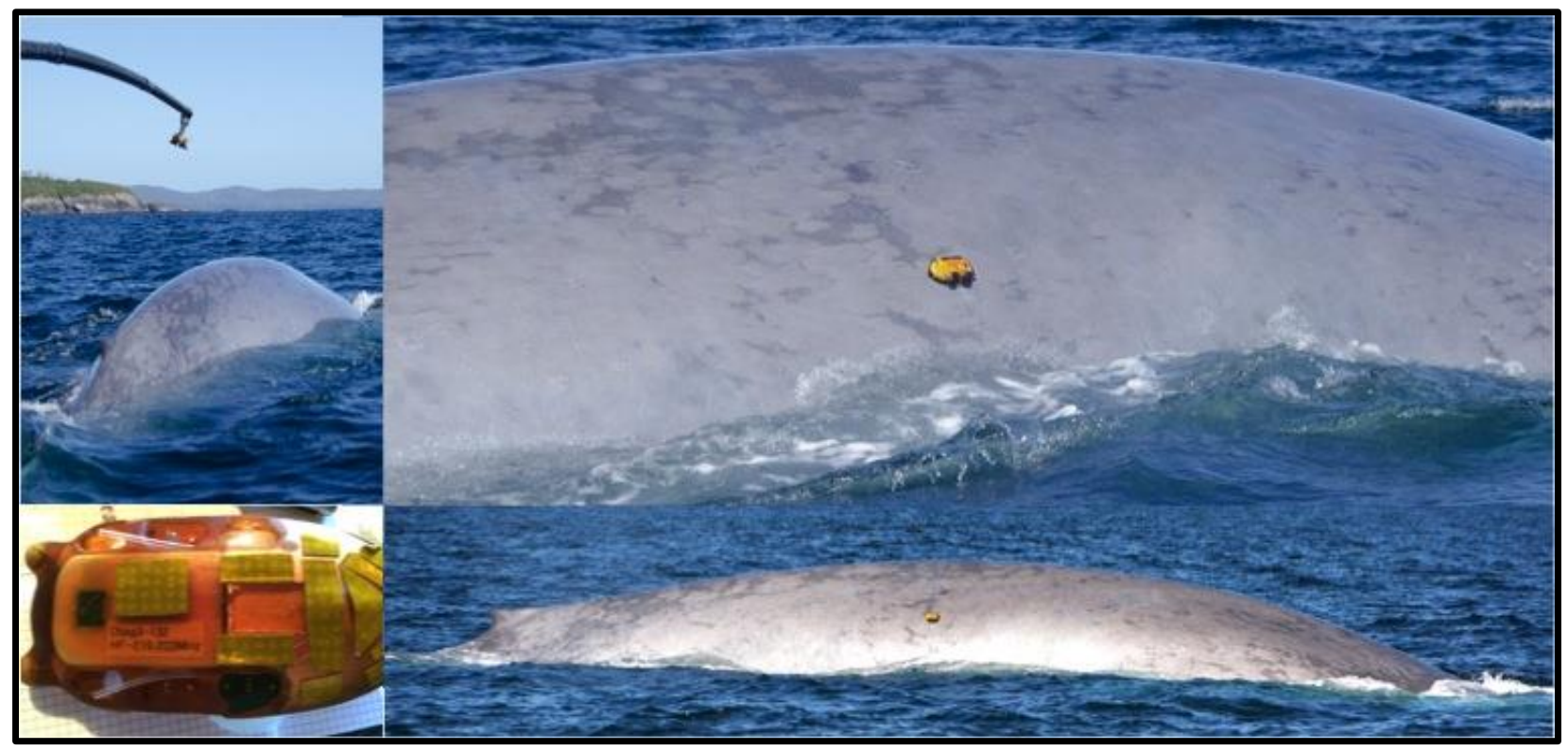

Figure 2. The DTAG (bottom left) and the attachment method via hand-held pole (top left); images on the right show the tag attached to a blue whale with its four suction cups and the tag's small size relative to the animal's size 


\section{Project Personnel and Research Vessel}

Cruise personnel included Alessandro Bocconcelli (WHOI), who was in charge of field operations, Leigh Hickmott (Open Ocean Consulting and the University of St. Andrews), who was in charge of data collection, and Rafaela Landea (MERI), who organized local logistics including obtaining research permits and additional observers. Gloria Howes (MERI) assisted with field logistics. Additional field personnel included Tessa Roorda (visual observations) and Daniel Casado (photographer and videographer). Laela Sayigh (WHOI) assisted with data analysis on shore. An $18.6 \mathrm{~m}$ fishing vessel, the MV Centinela, was employed as the principle survey vessel, and proved to be an ideal vessel for the experimental requirements (Fig. 3). The Centinela was capable of housing a scientific crew of 8, carrying and deploying a $4.2 \mathrm{~m}$ tagging boat (Zodiac with a $25 \mathrm{Hp} 4$ stroke engine) and providing a large and high visual observer platform.

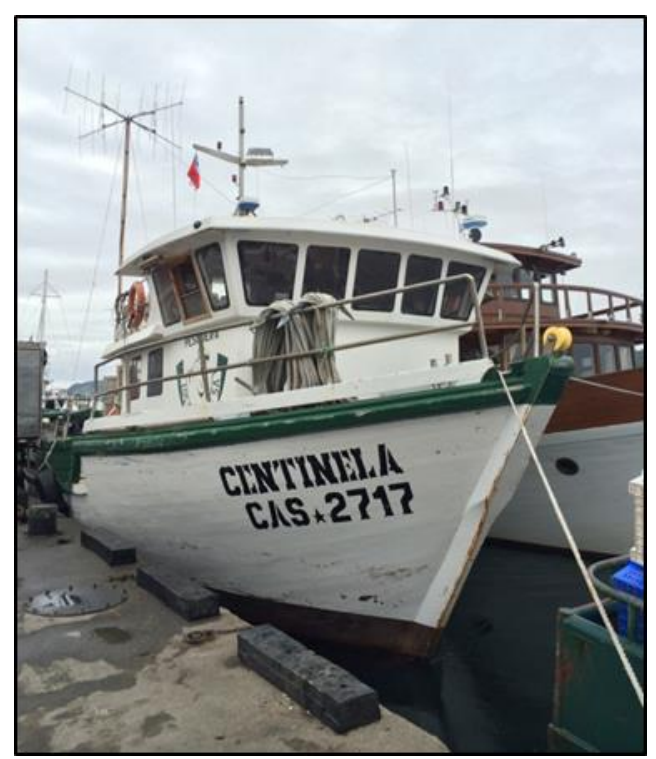

Figure 3. The MV Centinela

\section{Field Methods}

Each day, weather and sea-state permitting, visual search efforts to detect marine mammals began at sunrise on the main vessel. All cetacean sightings were recorded in LOGGER (see Tracking and Visual Data Collection below and Appendix I), and where possible photoidentification images were collected. Once blue whales were detected, the possibility for tagging was assessed and if conditions were suitable, tagging commenced.

3.1 Tracking, visual data collection and photo-identification - To visually search for animals to tag, and to observe the behavior of the animals during tagging and tracking, a marine mammal observer platform was installed on the deck of the flying bridge of the Centinela. Observers scanned with the naked eye and 7 X 50 binoculars. This platform was equipped with a computer 
running the behavior logging program LOGGER (recording data such as species, group size, behavior, latitude/longitude; see Appendix I) and a VHF digital direction finder system for tracking the tag. Video and/or digital photographs to record species and any identifying marks were collected whenever possible.

3.2 Tagging - The tagging boat was deployed with a driver (Bocconcelli), photographer (Daniel Casado) and tagger (Hickmott) to deliver the tag using the hand-pole. Attempts were made to tag each whale in a group when whales appeared to be coordinated and were likely to remain together, thus minimizing the risk of tag loss.

Visual observers on the main vessel helped direct the tag boat towards animals, monitored tagging approaches, and ensured tagging permit compliance. Data sheets and computer data logs were kept on the main vessel and tag boat, detailing each tagging approach. If tagging was unsuccessful after several approaches, tagging efforts were suspended. During tagging efforts video and/or $35 \mathrm{~mm}$ digital photographs were collected whenever possible, as were sloughed skin and fecal samples (see Genetic samples below).

Once a whale was successfully tagged and all relevant data collected by the tag team, the zodiac returned to the main vessel. The main vessel was then used to track and maintain visual and photo-identification efforts for the duration of tracking and behavioral observations (except for night hours). At night, the main VHF receiving antenna on the vessel was used for radio tracking of the tagged whale or whales (the main vessel was capable of tracking more than one animal using separate sets of antennae). Tagging attempts continued during daylight hours and a day was only considered complete when all tags were recovered and there was no longer enough daylight to attempt further tagging. Tags were recovered with a dip net from the main vessel. Tag data were offloaded onboard, and the tags were recharged and sterilized for subsequent use.

3.3 Genetic samples - Sloughed skin and fecal samples of whales were collected whenever possible for genetic (e.g. sexing, relatedness and population studies), dietary, and pollutant analyses. Sloughed skin could be found on the tags' suction cups. Fecal samples were collected with a tow net whenever observed. All samples were stored appropriately (20\% DMSO solution super-saturated with NaCL and frozen) and were left with MERI for analysis by Dr. Gustavo Chiang (University of Concepcion, Chile) as part of a wider study: 'Biomagnification and potential effects of Persistent Organic Pollutants (POPs) and trace metals in the aquatic food webs of the Antarctic Peninsula and Patagonia'.

3.4 Opportunistic recordings - Acoustic recordings were made opportunistically when other marine mammal species were encountered. During these encounters DTAGs were placed in the water to float in the vicinity of the animals, or attached to the tagging pole and held underwater to make recordings. 


\section{Results}

A thirteen day cruise was undertaken (15- 27 March 2014), departing the port of Dalcahue on Chiloé Island, Chile (Fig. 4). The $15^{\text {th }}$ and $16^{\text {th }}$ of March were used to prepare the vessel, equipment and transit to the primary study area. From the $17^{\text {th }}$ to the $27^{\text {th }}$, search efforts were focused within the Gulf of Corcovado, from Dalcahue on the eastern side of Chiloé Island, down to Melinka, Melimoyu and the northern output of the Moraleda channel (Fig. 4). During 11 workable sea days, more than $682 \mathrm{~nm}$ and 118 hours of 'on effort' survey were completed (Fig. 4). The survey effort generated 48 sightings of six cetacean species (Table $1 \&$ Fig. 5), all of which were within the known habitat region highlighted by the previous passive acoustic study (Figs. 1 and 5). In addition, there were numerous sightings of two otariid species, the South American sea lion (Otaria flavescens) and the South American fur seal (Arctocephalus australis), and one observation of a South American marine otter (Lontra felina). However, blue whales were the primary focus species of the cruise and search effort was biased towards finding this species.

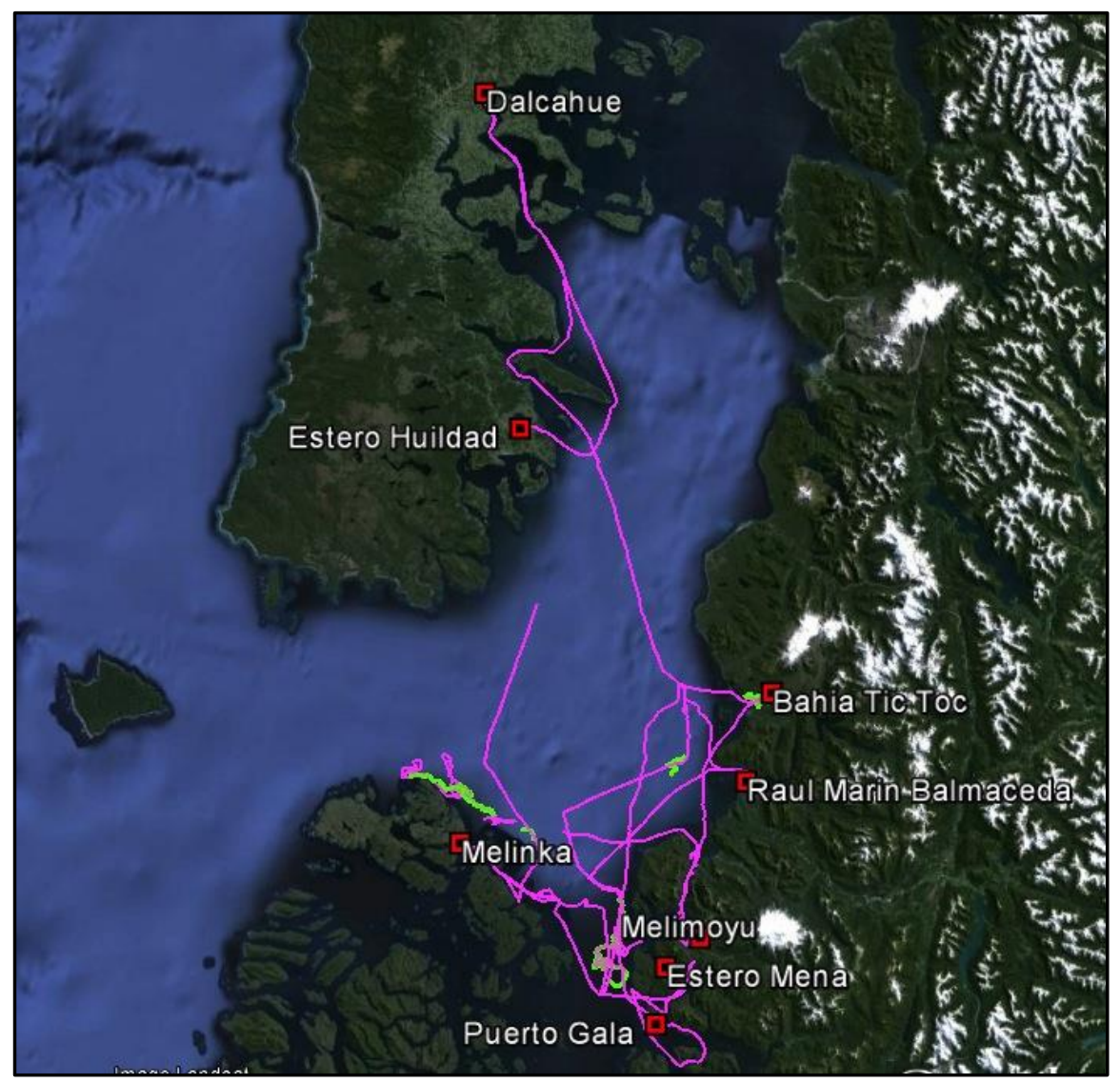

Figure 4 . The study area and vessel tracks (pink $=$ Centinela , green $=$ tag boat) 
Table 1. Cetacean species sighted, with the number of sightings per species, mean group size, standard deviation (SD) and range

\begin{tabular}{|c|c|c|c|c|}
\hline Scientific Name & $\begin{array}{c}\text { Common Name } \\
\text { (Spanish) }\end{array}$ & $\begin{array}{c}\text { Common Name } \\
\text { (English) }\end{array}$ & $\begin{array}{l}\text { Number of } \\
\text { sightings }\end{array}$ & $\begin{array}{c}\text { Mean group } \\
\text { size, SD } \\
\text { (range) }\end{array}$ \\
\hline $\begin{array}{c}\text { Balaenoptera } \\
\text { musculus }\end{array}$ & Ballena azul & Blue whale & 16 & $\begin{array}{l}1.1,0.3 \\
(1-2)\end{array}$ \\
\hline $\begin{array}{c}\text { Megaptera } \\
\text { novaeanglinae }\end{array}$ & Ballena Jorobada & $\begin{array}{c}\text { Humpback } \\
\text { whale }\end{array}$ & 14 & $\begin{array}{l}1.7,0.8 \\
(1-3)\end{array}$ \\
\hline $\begin{array}{l}\text { Tursiops } \\
\text { truncatus }\end{array}$ & Tursión & $\begin{array}{c}\text { Bottlenose } \\
\text { dolphin }\end{array}$ & 2 & $\begin{array}{c}45,7 \\
(40-50)\end{array}$ \\
\hline $\begin{array}{c}\text { Lagenorhynchus } \\
\text { australis }\end{array}$ & Delfín austral & Peale's Dolphin & 13 & $\begin{array}{c}3.8,3 \\
(1-12)\end{array}$ \\
\hline $\begin{array}{c}\text { Cephalorhynchus } \\
\text { eutropia }\end{array}$ & Delfín chileno & Chilean dolphin & 2 & $\begin{array}{c}5,4 \\
(2-8)\end{array}$ \\
\hline Orcinus orca & Orca & Killer whale & 1 & $1, \mathrm{NA}(1)$ \\
\hline
\end{tabular}

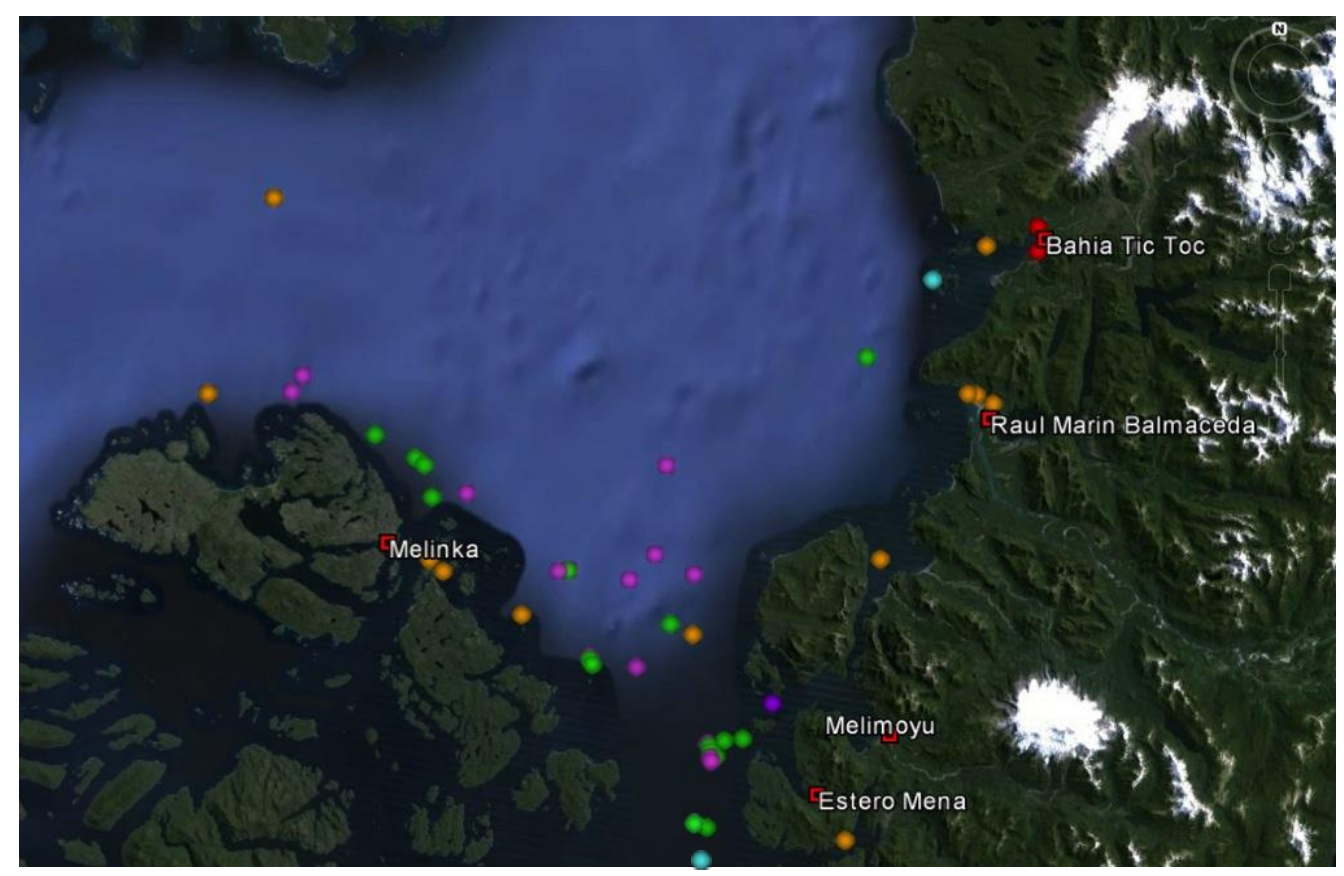

Key

Green = Blue whale

Pink = Humpback whale

Yellow $=$ Peale's dolphin

Blue = Bottlenose dolphin

Purple $=$ Killer whale

Red $\quad=$ Chilean dolphin

Figure 5. Locations of all cetacean sightings 
4.1 Photo-identification - Photo-identification images $(12,605)$ were collected of seven marine mammal species during 30 encounters, as summarized in Table 2 . Ten blue whale groups were photo documented on eight survey days between the $17^{\text {th }}$ and $24^{\text {th }}$ of March (Tables 3 and 4 ). A total of five different individuals were photo-identified (Fig. 6). All encounters were with individual animals except for a pair of whales (Bm004 and Bm005) seen on the $23^{\text {rd }}$ of March, resulting in a mean group size of 1.1 (S.D. 0.3) animals. Bm001 was seen on six occasions between the $17^{\text {th }}$ and $22^{\text {nd }}$ of March. Bm003 was seen on two occasions, the $23^{\text {rd }}$ and $24^{\text {th }}$ March. The other three blue whales were each encountered only once.

Table 2. Marine mammal species documented using photo-identification, with the number of encounters per species

\begin{tabular}{|c|c|c|}
\hline Scientific Name & Common Name & Number of Photo-ID Encounters \\
\hline Balaenoptera musculus & Blue whale & 10 \\
\hline Megaptera novaeanglinae & Humpback whale & 10 \\
\hline Tursiops truncatus & Bottlenose dolphin & 1 \\
\hline Lagenorhynchus australis & Peale's Dolphin & 4 \\
\hline Cephalorhynchus eutropia & Chilean dolphin & 2 \\
\hline Otaria flavescens & South American sea lion & 1 \\
\hline Arctocephalus australis & South American fur seal & 2 \\
\hline
\end{tabular}

Table 3. Blue whale encounter and photo-identification summaries

\begin{tabular}{|c|c|c|l|c|}
\hline Date & Time (local) & Group size & IDs & Age class \\
\hline 17-Mar-14 & $12: 18$ & 1 & Chile14_Bm001 & Adult \\
\hline 18-Mar-14 & $10: 55$ & 1 & Chile14_Bm001 & Adult \\
\hline 19-Mar-14 & $10: 51$ & 1 & Chile14_Bm001 & Adult \\
\hline 20-Mar-14 & $15: 50$ & 1 & Chile14_Bm001 & Adult \\
\hline 21-Mar-14 & $09: 10$ & 1 & Chile14_Bm001 & Adult \\
\hline 21-Mar-14 & $18: 12$ & 1 & Chile14_Bm002 & $\begin{array}{c}\text { Juvenile/ } \\
\text { Sub-adult }\end{array}$ \\
\hline 22-Mar-14 & $15: 37$ & 1 & Chile14_Bm001 & Adult \\
\hline 23-Mar-14 & $08: 32$ & 1 & Chile14_Bm003 & Adult \\
\hline 23-Mar-14 & $12: 49$ & 2 & $\begin{array}{c}\text { Chile14_Bm004 } \\
\text { Chile14_Bm005 }\end{array}$ & $\begin{array}{c}\text { Adult } \\
\text { Sub-adult }\end{array}$ \\
\hline 24-Mar-14 & $08: 31$ & 1 & Chile14_Bm003 & Adult \\
\hline
\end{tabular}




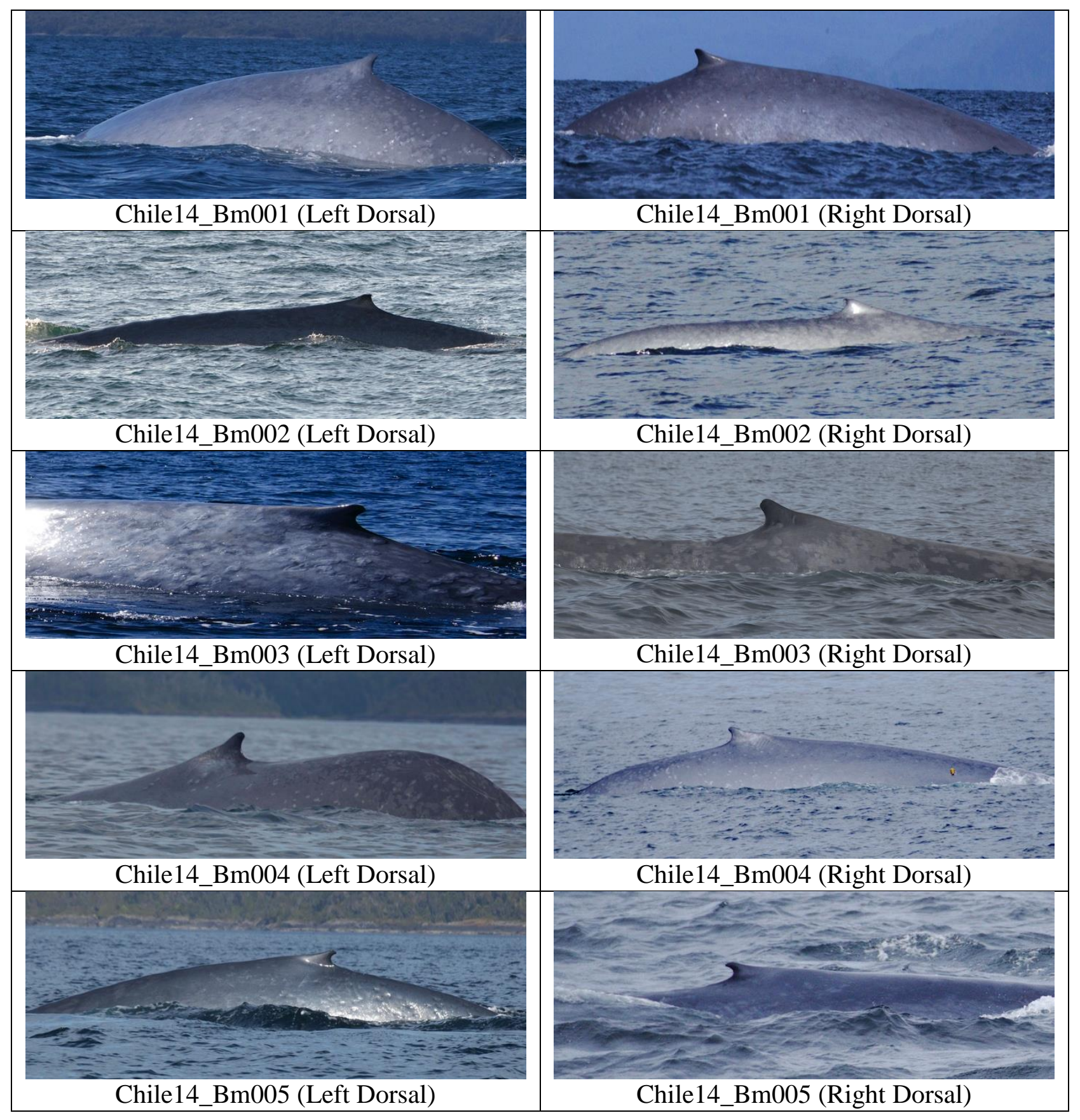

Figure 6. Photo-identification images of the five blue whales photo-identified during the cruise 
Table 4. Latitudes and longitudes of all locations where blue $(\mathrm{Bm})$ and humpback $(\mathrm{Mn})$ whales were photo-identified

\begin{tabular}{|c|c|c|c|}
\hline Date & Whale ID & Latitude & Longitude \\
\hline \multirow[t]{3}{*}{ 17-Mar-14 } & Chile14_Bm001 & 44.174 & 73.3451 \\
\hline & Chile14_Mn001 & 44.0955 & 73.3271 \\
\hline & Chile14_Mn002 & 44.0955 & 73.3271 \\
\hline 18-Mar-14 & Chile14_Bm001 & 44.0927 & 73.3056 \\
\hline 19-Mar-14 & Chile14_Bm001 & 43.9786 & 73.3768 \\
\hline 20-Mar-14 & Chile14_Bm001 & 44.013 & 73.4839 \\
\hline \multirow[t]{6}{*}{ 21-Mar-14 } & Chile14_Bm001 & 44.0184 & 73.4799 \\
\hline & Chile14_Bm002 & 43.7159 & 73.1169 \\
\hline & Chile14_Mn002 & 44.0206 & 73.3816 \\
\hline & Chile14_Mn003 & 44.0104 & 73.4836 \\
\hline & Chile14_Mn004 & 44.0206 & 73.3816 \\
\hline & Chile14_Mn005 & 44.0206 & 73.3816 \\
\hline \multirow[t]{6}{*}{ 22-Mar-14 } & Chile14_Bm001 & 43.9262 & 73.5117 \\
\hline & Chile14_Mn004 & 43.9249 & 73.6454 \\
\hline & Chile14_Mn006 & 43.8229 & 73.3816 \\
\hline & Chile14_Mn007 & 43.8229 & 73.3816 \\
\hline & Chile14_Mn008 & 43.9103 & 73.3966 \\
\hline & Chile14_Mn009 & 43.9266 & 73.5243 \\
\hline \multirow[t]{4}{*}{ 23-Mar-14 } & Chile14_Bm003 & 43.8537 & 73.6915 \\
\hline & Chile14_Bm004 & 43.8225 & 73.7013 \\
\hline & Chile14_Bm005 & 43.8225 & 73.7013 \\
\hline & Chile14_Mn009 & 43.8499 & 73.6454 \\
\hline \multirow[t]{5}{*}{ 24-Mar-14 } & Chile14_Bm003 & 43.7925 & 73.7666 \\
\hline & Chile14_Mn008 & 43.7499 & 73.8764 \\
\hline & Chile14_Mn009 & 43.7499 & 73.8764 \\
\hline & Chile14_Mn010 & 43.7337 & 73.8618 \\
\hline & Chile14_Mn011 & 43.7337 & 73.8618 \\
\hline
\end{tabular}

Groups of humpback whales were seen on ten occasions during five survey days between the $17^{\text {th }}$ and $24^{\text {th }}$ of March (Tables 4 and 5). Eleven individuals were photo-identified, consisting of nine adult animals; two of these adults (presumed females) were accompanied by juveniles (Table 5, Figure 7). The mean group size was 1.7 (S.D. 0.8) individuals. Of the eleven animals, Mn009 was resighted the most, being seen on three different days, the $22^{\text {nd }}, 23^{\text {rd }}$ and $24^{\text {th }}$ of March. Mn002 was seen on two occasions, the $17^{\text {th }}$ and $21^{\text {st }}$ of March, and was with different individuals in the two sightings. Mn004 and Mn008 were also each encountered twice, Mn004 on the $21^{\text {st }}$ and $22^{\text {nd }}$ of March and Mn008 on the $22^{\text {nd }}$ and $24^{\text {th }}$ of March. The other seven humpback whales were each only observed once. 
Table 5. Humpback whale encounter and photo-identification summaries

\begin{tabular}{|c|c|c|l|c|}
\hline Date & Time (local) & Group size & IDs & Age class \\
\hline 17-Mar-14 & $12: 14$ & 3 & $\begin{array}{l}\text { Chile14_Mn001 } \\
\text { Chile14_Mn002 }\end{array}$ & $\begin{array}{r}\text { Adult } \\
\text { Adult }\end{array}$ \\
\hline 21-Mar-14 & $09: 50$ & 1 & Chile14_Mn003 & Adult \\
\hline 21-Mar-14 & $10: 19$ & 3 & $\begin{array}{l}\text { Chile14_Mn004 } \\
\text { Chile14_Mn005 } \\
\text { Chile14_Mn002 }\end{array}$ & $\begin{array}{r}\text { Adult } \\
\text { Adult } \\
\text { Adult }\end{array}$ \\
\hline 22-Mar-14 & $11: 13$ & 2 & $\begin{array}{l}\text { Chile14_Mn006 } \\
\text { Chile14_Mn007 }\end{array}$ & $\begin{array}{c}\text { Adult } \\
\text { Juvenile }\end{array}$ \\
\hline 22-Mar-14 & $12: 01$ & 1 & Chile14_Mn008 & Adult \\
\hline 22-Mar-14 & $14: 55$ & 1 & Chile14_Mn009 & Adult \\
\hline 22-Mar-14 & $15: 09$ & 1 & Chile14_Mn004 & Adult \\
\hline 23-Mar-14 & $09: 07$ & 1 & Chile14_Mn009 & Adult \\
\hline 24-Mar-14 & $16: 49$ & 2 & $\begin{array}{l}\text { Chile14_Mn008 } \\
\text { Chile14_Mn009 }\end{array}$ & $\begin{array}{c}\text { Adult } \\
\text { Adult }\end{array}$ \\
\hline 24-Mar-14 & $17: 00$ & 2 & $\begin{array}{l}\text { Chile14_Mn010 } \\
\text { Chile14_Mn011 }\end{array}$ & $\begin{array}{r}\text { Adult } \\
\text { Juvenile }\end{array}$ \\
\hline
\end{tabular}

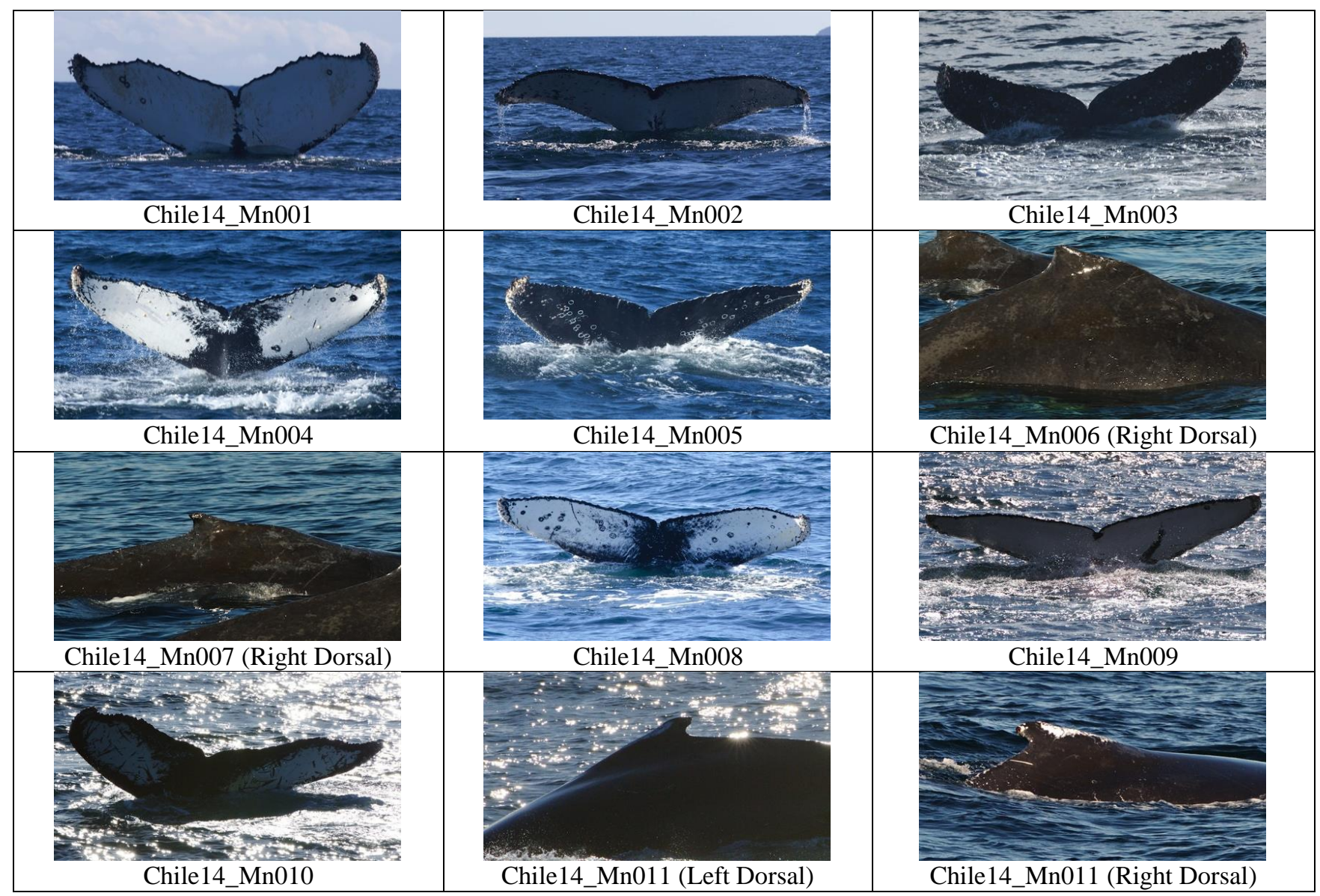

Figure 7. Photo-identification images of the 11 humpback whales photo-identified during the cruise 
4.2 DTAG effort - The tag boat was launched on six occasions to attempt tagging, and covered over $93 \mathrm{~nm}$ during focal follows and tagging efforts. A total of 21 hours $11 \mathrm{~min}$ of blue whale DTAG data were collected, consisting of five tag deployments on four individual blue whales (Table 6). The mean deployment duration was $4.5 \mathrm{hr}$ (S.D. 4.3), with the longest at $10 \mathrm{hr} 08 \mathrm{~min}$. Sloughed skin was found on the suction cups of all recovered tags and high sloughing rates may have been the cause for early releases in some of the deployments. Dives were generally shallow, predominantly between 10 and 50 meters in depth (Fig. 8). Occasional deeper dives were recorded, with a maximum depth of $139 \mathrm{~m}$. The consistent shallow nature of dives suggests that prey were present at these shallow depths. In all deployments the tags operated well, recording acoustic and movement data during periods of both travel and foraging. DTAG audio was sampled at $500 \mathrm{kHz}$ and other sensors at $50 \mathrm{~Hz}$. One simultaneous deployment was achieved, of a presumed mother and juvenile pair (Table 6).

Table 6. Blue whale DTAG deployment summaries

\begin{tabular}{|c|c|c|c|c|c|}
\hline Date & $\begin{array}{c}\text { Animal } \\
\text { ID }\end{array}$ & $\begin{array}{c}\text { Age } \\
\text { Class }\end{array}$ & $\begin{array}{c}\text { Deployment } \\
\text { ID }\end{array}$ & $\begin{array}{c}\text { Deployment } \\
\text { Duration } \\
\text { (Hr:min) }\end{array}$ & $\begin{array}{c}\text { Deployment Time } \\
\text { (local) \& Location }\end{array}$ \\
\hline 17-Mar-14 & Bm001 & Adult & bm14_076a & 0 hrs 07 min & $\begin{array}{c}13: 15-44.13916^{\circ} \mathrm{S} \\
73.34236^{\circ} \mathrm{W}\end{array}$ \\
\hline 17-Mar-14 & Bm001 & Adult & bm14_076b & 5 hrs 53 min & $\begin{array}{c}18: 36-44.09475^{\circ} \mathrm{S} \\
73.32693^{\circ} \mathrm{W}\end{array}$ \\
\hline 23-Mar-14 & Bm004 & Adult & bm14_082a & $3 \mathrm{hrs} 46 \mathrm{~min}$ & $\begin{array}{c}13: 00-43.78268^{\circ} \mathrm{S} \\
73.74951^{\circ} \mathrm{W}\end{array}$ \\
\hline 23-Mar-14 & Bm005 & $\begin{array}{c}\text { Juvenile/ } \\
\text { subadult }\end{array}$ & bm14_082b & $1 \mathrm{hr} 18 \mathrm{~min}$ & $\begin{array}{c}13: 59-43.80112^{\circ} \mathrm{S} \\
73.72539^{\circ} \mathrm{W}\end{array}$ \\
\hline 24-Mar-14 & Bm003 & Adult & bm14_083a & $10 \mathrm{hrs} \mathrm{07} \mathrm{min}$ & $\begin{array}{c}13: 22-43.75878^{\circ} \mathrm{S} \\
73.88860^{\circ} \mathrm{W}\end{array}$ \\
\hline
\end{tabular}

Acoustic data on the tags revealed numerous faint (non-focal) blue whale calls, characteristic of those described previously in this area by Cummings and Thompson (1971) and Buchan et al. (2010, 2014). In addition, in the one simultaneous tag deployment of a presumed mother (bm082a) and juvenile (bm082b), an apparent call exchange was observed between the juvenile whale and a more distant animal (Figure 9). We can confirm that the call was not produced by the mother, because it was quieter on her tag than on the juvenile's tag (Figure 9). Further confirmation that the call came from the juvenile whale came from a signal on the tag's accelerometers, which were sampled at a high enough frequency $(50 \mathrm{~Hz})$ to detect calls at or below $25 \mathrm{~Hz}$. This method of caller identification for baleen whales that produce low frequency calls, such as blue and fin whales, was recently described by Goldbogen et al. (2014). 

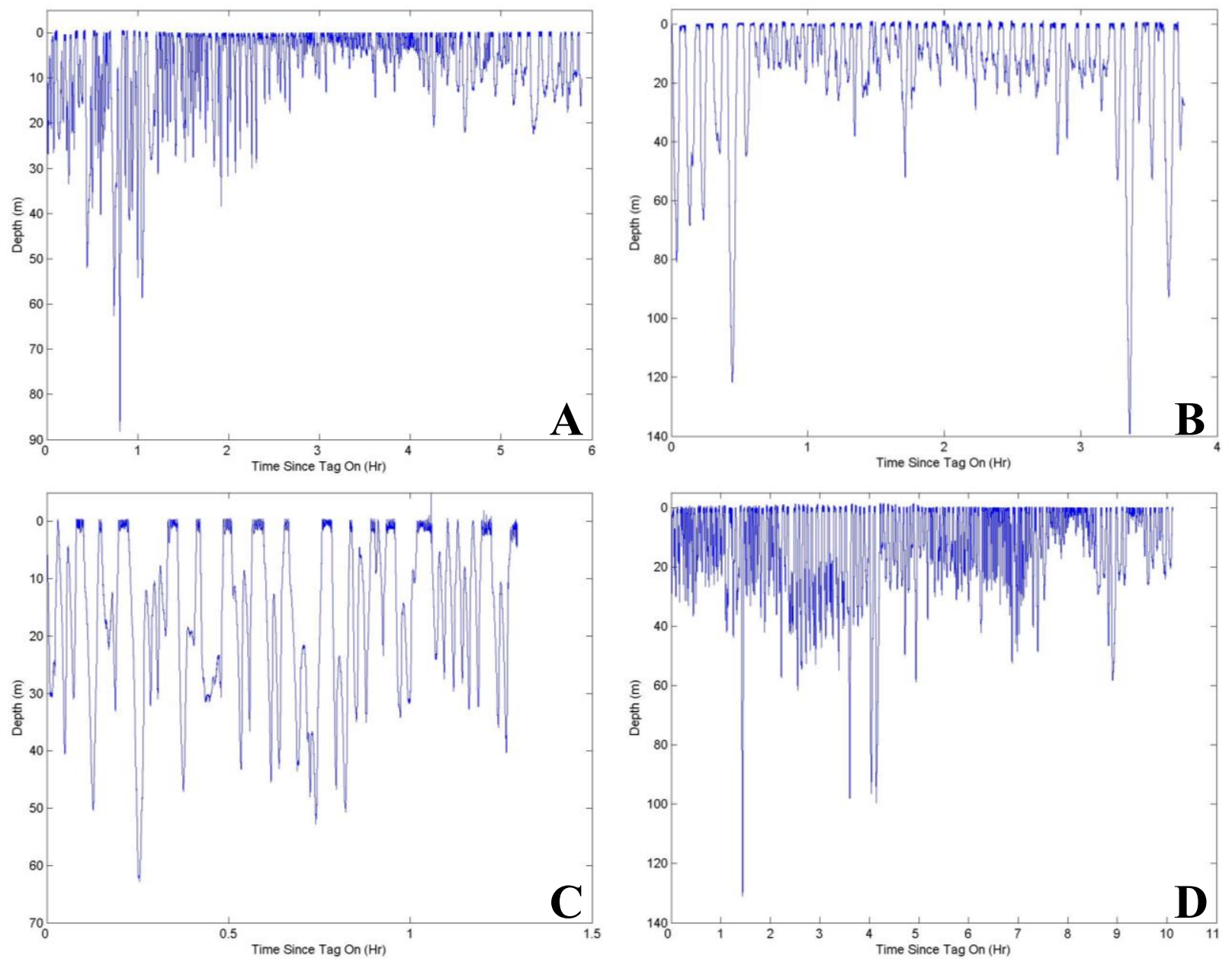

Figure 8. Dive profiles of four tagged blue whales. A = bm14_076b (Bm001), B = bm14_082a (Bm004), $\mathrm{C}=$ bm14_082b $(\mathrm{Bm005}), \mathrm{D}=\mathrm{bm14} \_083 \mathrm{a}(\mathrm{Bm003})$

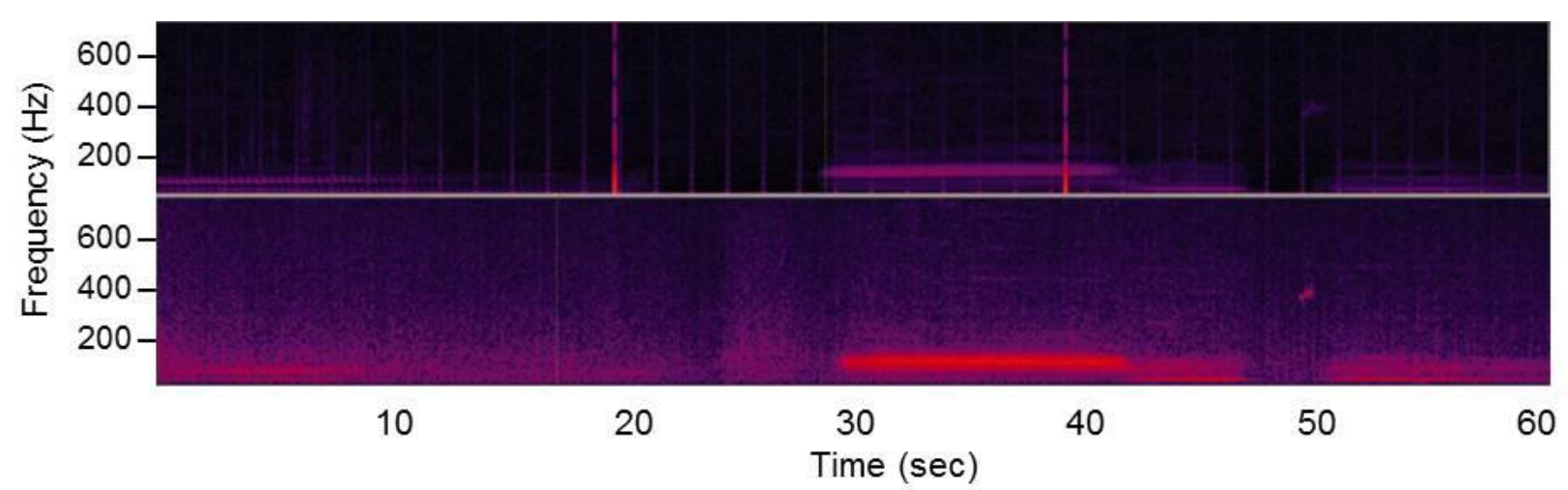

Figure 9. Spectrograms (plots of frequency vs. time) of sounds recorded on the tags of the presumed mother (Bm004, top) and juvenile ((Bm005, bottom). Note that the call is louder on the juvenile's tag; confirmation of its production by the juvenile came from its detection on the juvenile's tag's accelerometers (see text). This call type is characteristic of those described for blue whales in this area, including a higher frequency component (approximately $400 \mathrm{~Hz}$ ) that is visible at around $50 \mathrm{sec}$. The faint vertical lines evident in the upper spectrogram are the boat's echosounder, and the two more distinct lines at approximately 20 and $40 \mathrm{sec}$ are of unknown origin. 
4.3 Genetic samples - During the field effort genetic samples were opportunistically collected from both blue and humpback whales (Table 7). Five sloughed skin samples were collected from the DTAG suction cups from four different blue whales (Bm001, Bm003, Bm004 and Bm005). $\mathrm{Bm} 004$ and Bm005 were close associates that were tagged simultaneously and are a presumed mother and juvenile; the genetic results will confirm or refute this assumption. Three fecal samples were collected during the cruise, two from blue whales (Bm003 and Bm005) and one from a humpback whale (Mn004). In both blue whale samples, krill exoskeleton remains were clearly identifiable.

Table 7. Summary information for eight genetic samples collected from blue and humpback whales; all samples were stored in DMSO/NaCl and will be analyzed by Dr. Gustavo Chiang Rojas at the Universidad de Concepcion, as a joint MERI/WHOI project

\begin{tabular}{|c|c|c|c|c|c|}
\hline Date & Species & $\begin{array}{c}\text { Sample } \\
\text { Type }\end{array}$ & $\begin{array}{l}\text { Age } \\
\text { Class }\end{array}$ & $\begin{array}{l}\text { Collection } \\
\text { Time (local) } \\
\text { \& Location }\end{array}$ & Animal ID \\
\hline 17-Mar-14 & $\begin{array}{l}\text { Blue whale } \\
(\mathrm{Bm})\end{array}$ & Skin & Adult & $\begin{array}{c}13: 22- \\
44.13746^{\circ} \mathrm{S} \\
73.34933^{\circ} \mathrm{W}\end{array}$ & bm14_076a \\
\hline 17-Mar-14 & $\begin{array}{l}\text { Blue whale } \\
(\mathrm{Bm})\end{array}$ & Skin & Adult & $\begin{array}{c}23: 40- \\
44.11875^{\circ} \mathrm{S} \\
73.31979^{\circ} \mathrm{W}\end{array}$ & bm14_076b \\
\hline 22-Mar-14 & $\begin{array}{l}\text { Humpback } \\
\text { whale (Mn) }\end{array}$ & Feces & Adult & $\begin{array}{c}15: 13- \\
43.9249^{\circ} \mathrm{S} \\
73.5104^{\circ} \mathrm{W}\end{array}$ & Chile14_Mn004 \\
\hline 23-Mar-14 & $\begin{array}{c}\text { Blue whale } \\
(\mathrm{Bm})\end{array}$ & Skin & $\begin{array}{c}\text { Juvenile/ } \\
\text { subadult }\end{array}$ & $\begin{array}{c}15: 21- \\
43.77053^{\circ} \mathrm{S} \\
73.77253^{\circ} \mathrm{W}\end{array}$ & $\begin{array}{c}\text { bm14_082b - } \\
\text { possibly offspring } \\
\text { of bm14_082a }\end{array}$ \\
\hline 23-Mar-14 & $\begin{array}{c}\text { Blue whale } \\
(\mathrm{Bm})\end{array}$ & Skin & Adult & $\begin{array}{c}17: 01- \\
43.7462^{\circ} \mathrm{S} \\
73.7764^{\circ} \mathrm{W}\end{array}$ & $\begin{array}{c}\text { bm14_082a - } \\
\text { possibly mother } \\
\text { of bm14_082b }\end{array}$ \\
\hline 23-Mar-14 & $\begin{array}{l}\text { Blue whale } \\
(\mathrm{Bm})\end{array}$ & Feces & $\begin{array}{l}\text { Juvenile/ } \\
\text { subadult }\end{array}$ & $\begin{array}{c}13: 59- \\
43.80112^{\circ} \mathrm{S} \\
73.72539^{\circ} \mathrm{W}\end{array}$ & bm14_082b \\
\hline 24-Mar-14 & $\begin{array}{c}\text { Blue whale } \\
(\mathrm{Bm})\end{array}$ & Feces & Adult & $\begin{array}{c}10: 27- \\
43.7889^{\circ} \mathrm{S} \\
73.79484^{\circ} \mathrm{W}\end{array}$ & bm14_083a \\
\hline 24-Mar-14 & $\begin{array}{c}\text { Blue whale } \\
(\mathrm{Bm})\end{array}$ & Skin & Adult & $\begin{array}{c}23: 30- \\
43.79589^{\circ} \mathrm{S} \\
73.75749^{\circ} \mathrm{W}\end{array}$ & bm14_083a \\
\hline
\end{tabular}


4.4 Opportunistic acoustic recordings - On five occasions acoustic recordings were made of other species (Table 8): Peale's dolphins (Lagenorhynchus australis), Chilean dolphins (Cephalorhynchus eutropia), bottlenose dolphins (Tursiops truncatus) and South American fur seals (Arctocephalus australis), for a total of 3.2 hours of recordings. On the evening of 26/03/14, a floating DTAG was deployed overnight tethered to the Centinela (from 20:45 hrs to 07:27 hrs on 27/03), in an attempt to make recordings of Cephalorhynchus eutropia, which had been observed in the area.

Table 8. Details regarding opportunistic acoustic recordings made of other encountered species

\begin{tabular}{|l|l|c|c|l|l|}
\hline \multicolumn{1}{|c|}{ Species } & Date & $\begin{array}{c}\text { Recording } \\
\text { Location }\end{array}$ & $\begin{array}{c}\text { Recording } \\
\text { Duration }\end{array}$ & $\begin{array}{l}\text { Recording } \\
\text { Frequency }\end{array}$ & \multicolumn{1}{|c|}{ Observed Behavior } \\
\hline $\begin{array}{l}\text { Tursiops truncatus } \\
\text { and Arctocephalus } \\
\text { australis }\end{array}$ & $03 / 21 / 14$ & $\begin{array}{c}43.6379^{\circ} \mathrm{S} \\
73.06^{\circ} \mathrm{W}\end{array}$ & $31 \mathrm{~min}$ & $240 \mathrm{kHz}$ & $\begin{array}{l}\text { Bottlenose dolphins (50+) } \\
\text { and fur seals socializing at } \\
\text { the surface }\end{array}$ \\
\hline $\begin{array}{l}\text { Lagenorhynchus } \\
\text { australis }\end{array}$ & $03 / 26 / 14$ & $\begin{array}{c}43.9112^{\circ} \mathrm{S} \\
73.1136^{\circ} \mathrm{W}\end{array}$ & $1 \mathrm{hr} 20 \mathrm{~min}$ & $500 \mathrm{kHz}$ & $\begin{array}{l}5 \text { dolphins foraging } \\
\text { approximately } 600 \mathrm{~m} \text { from } \\
\text { the zodiac, calm and } \\
\text { moving slowly }\end{array}$ \\
\hline $\begin{array}{l}\text { Cephalorhynchus } \\
\text { eutropia }\end{array}$ & $03 / 26 / 14$ & $\begin{array}{c}43.6156^{\circ} \mathrm{S} \\
72.9102^{\circ} \mathrm{W}\end{array}$ & $20 \mathrm{~min}$ & $500 \mathrm{kHz}$ & $\begin{array}{l}\text { 2 dolphins swimming by } \\
\text { the shoreline, close to the } \\
\text { zodiac }\end{array}$ \\
\hline $\begin{array}{l}\text { Lagenorhynchus } \\
\text { australis }\end{array}$ & $03 / 26 / 14$ & $\begin{array}{c}43.6057^{\circ} \mathrm{S} \\
72.9591^{\circ} \mathrm{W}\end{array}$ & $19 \mathrm{~min}$ & $500 \mathrm{kHz}$ & $\begin{array}{l}\text { 12 dolphins socializing and } \\
\text { foraging near the zodiac }\end{array}$ \\
\hline $\begin{array}{l}\text { Cephalorhynchus } \\
\text { eutropia }\end{array}$ & $03 / 26 / 14$ & $\begin{array}{c}43.5978^{\circ} \mathrm{S} \\
72.8882^{\circ} \mathrm{W}\end{array}$ & $43 \mathrm{~min}$ & $500 \mathrm{kHz}$ & $\begin{array}{l}\text { 8 animals foraging near the } \\
\text { zodiac }\end{array}$ \\
\hline$*$ Not identified & $03 / 26 / 14$ & $\begin{array}{c}43.6126^{\circ} \mathrm{S} \\
72.8918^{\circ} \mathrm{W}\end{array}$ & $10 \mathrm{hrs} 48$ \\
min & $240 \mathrm{kHz}$ & $\begin{array}{l}\text { A tag was tethered to the } \\
\text { vessel to make an overnight } \\
\text { recording in an area where } \\
\text { Chilean dolphins had been } \\
\text { observed }\end{array}$ \\
\hline
\end{tabular}

All recordings contained sounds produced by the species of interest, except for the overnight recording. The recording made of bottlenose dolphins and fur seals contains numerous whistles characteristic of bottlenose dolphin signature whistles (e.g., Sayigh et al. 2007); a section of this recording is shown in Figure 10. Clicks from Peale's dolphins (Lagenorhynchus australis) and Chilean dolphins (Cephalorhynchus eutropia) are shown in Figures 11 and 12, respectively. Both of these species produce narrow band, high frequency clicks with very similar characteristics (Gotz et al. 2010, Kyhn et al. 2010), and thus are difficult to differentiate; attributions made here are based on which species were observed to be in the area when recordings were made. 


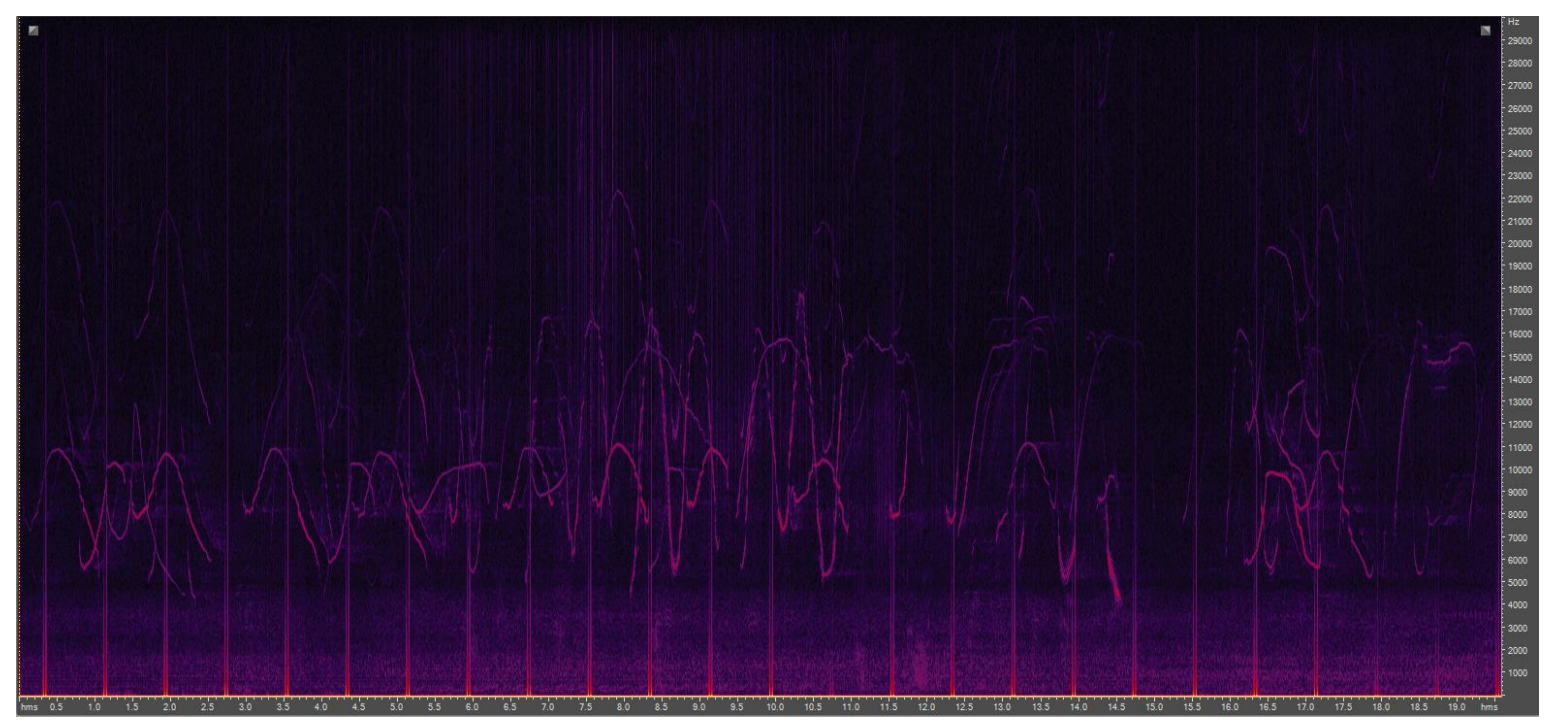

Figure 10. Spectrogram of a section of a recording made by a DTAG floating in the vicinity of a group of bottlenose dolphins (Tursiops truncatus) and South American fur seals (Arctocephalus australis. Stereotyped contours characteristic of bottlenose dolphin signature whistles are evident (y axis: frequency in $\mathrm{Hz}, \mathrm{x}$ axis: time in sec); vertical lines are the boat's echosounder

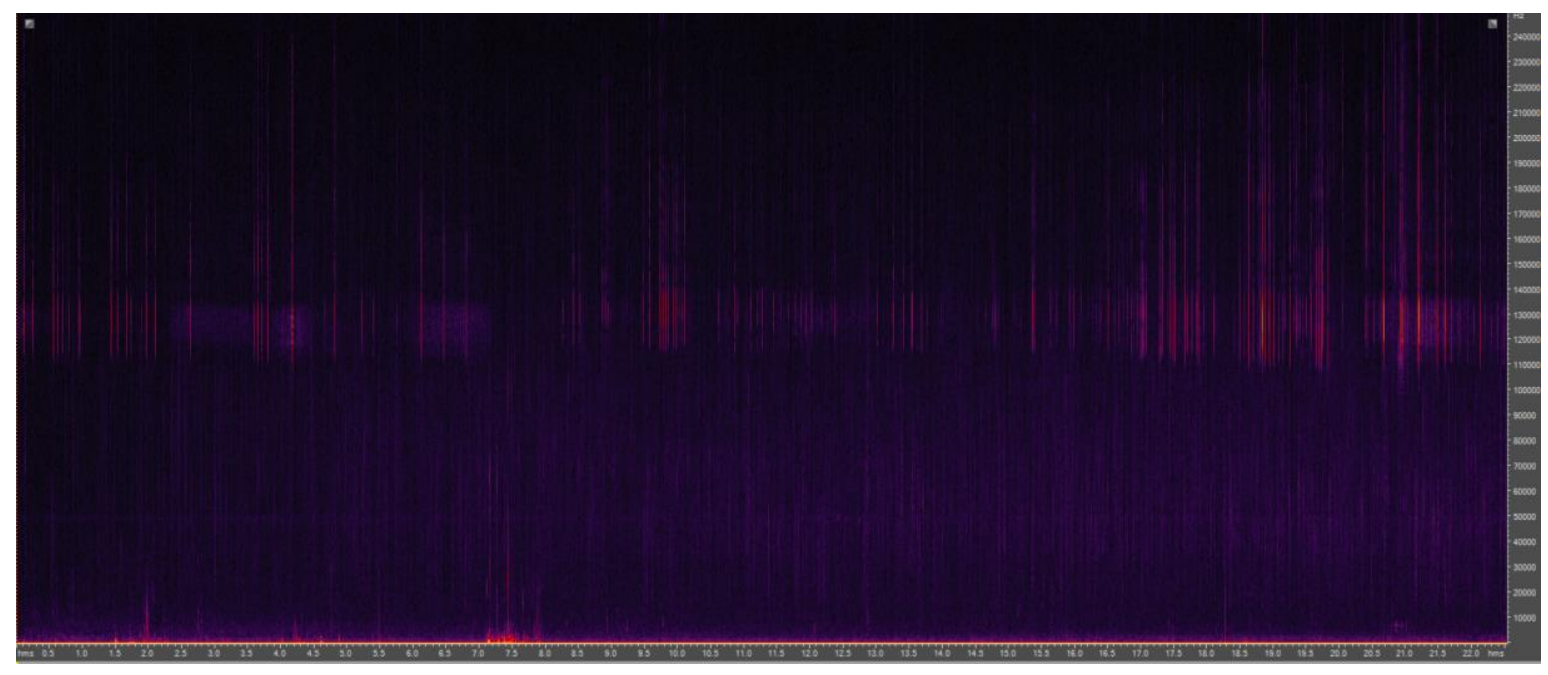

Figure 11. Spectrogram of a section of a recording made by a DTAG on a tag pole held down in the water while a group of five Peale's dolphins were within $600 \mathrm{~m}$ of the tag boat (y axis: frequency in $\mathrm{Hz}$, $\mathrm{x}$ axis: time in sec); clicks are evident between about 110000 and $200000 \mathrm{~Hz}$ 


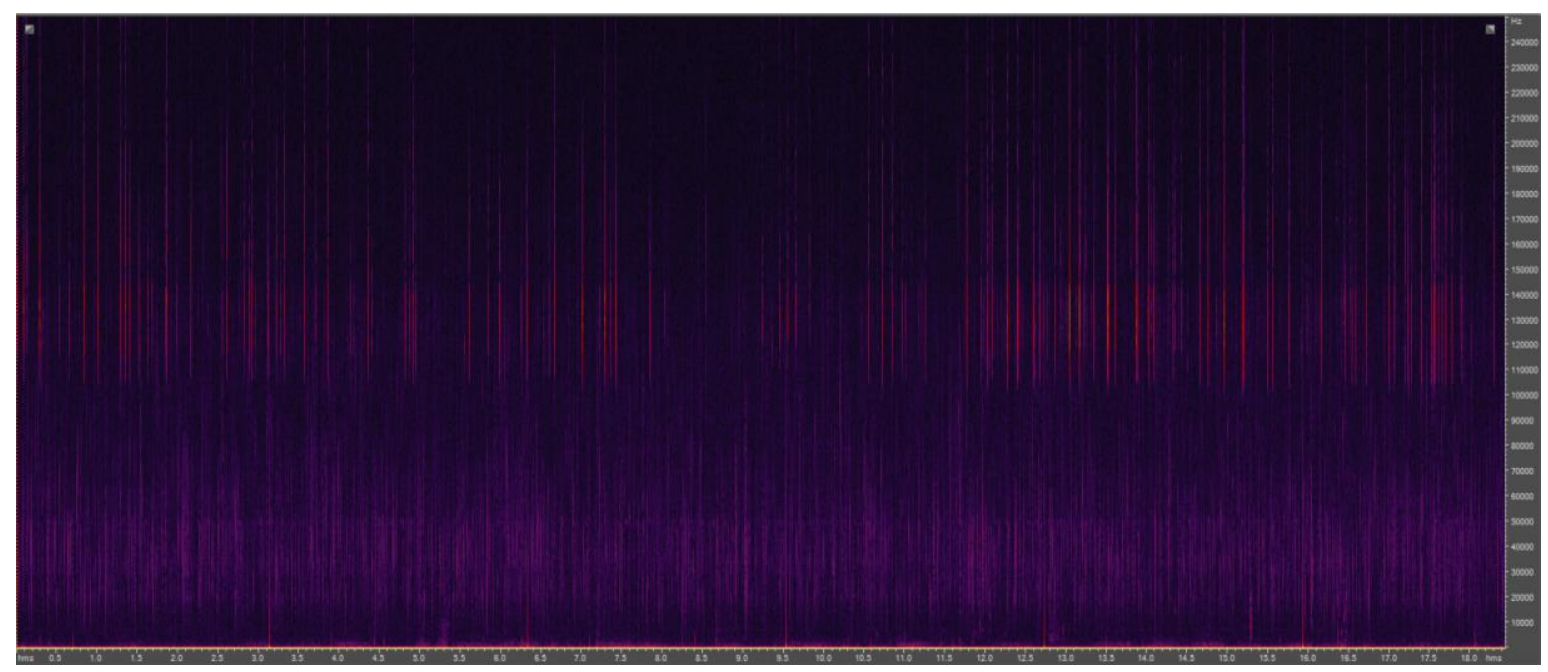

Figure 12. Spectrogram of a section of a recording made by a DTAG on a tag pole held down in the water while a group of eight Chilean dolphins were foraging near the tag boat (y axis: frequency in $\mathrm{Hz}, \mathrm{x}$ axis: time in sec); clicks are evident between about 110000 and $200000 \mathrm{~Hz}$

\section{Impact and future work}

This exploratory cruise proved highly successful and a strong collaborative relationship was established between the MERI and WHOI teams. The five DTAG deployments are the first records collected on the detailed movements and foraging behavior of blue whales in the Gulf of Corcovado. The proven approach and techniques employed by the team worked well in this remote field location. The field site demonstrated excellent potential for future blue whale research as well as studies of other species. The unique combination of the gulf and fjord habitats enabled the team to be very productive, working in the gulf when conditions permitted and in the fjords during periods of high wind.

Future work planned includes a one week Marine Mammal Biology course, to be taught in Chile, which will include background on marine mammal biology, ecology, and behavior, focusing on the species that occur in Corcovado Bay. Students will be taken out on a MERI vessel, to be trained in data collection techniques for marine mammals and the marine environment, including acoustic recordings, photo-identification, plankton sampling, and water sampling, including conductivity, temperature and depth (CTD), salinity and turbidity testing. Laela Sayigh and Alessandro Bocconcelli will teach this class. Additional local outreach efforts will be initiated by MERI through lectures and development of educational materials.

In addition, moorings equipped with passive acoustic monitors (PAM) will be deployed in critical habitat areas for marine mammals. Alessandro Bocconcelli will carry out the initial deployments and will train MERI researchers to retrieve and re-deploy them periodically. Laela 
Sayigh will analyze the acoustic data collected. Preliminary funds have been received for this work from the WHOI Marine Mammal Center. Finally, continued tagging of blue whales will take place, along with photogrammetric measurements of body condition by means of aerial photographs taken with a hexacopter. Preliminary funding for this work has been obtained from the WHOI Access to the Sea program (Michael Moore, PI). In this field effort, biopsies will be obtained of all animals that are tagged, as well as of additional animals whenever possible, in order to obtain data on sex and genetic relationships among the animals, as well as information about diet through stable isotope analysis, and about health parameters through pollutant analyses. Acoustic data collected on tags will provide individual call rates necessary to make density estimations from PAM recordings (Marques et al. 2013), and tag sensor data can be used to reconstruct 3-dimensional movements and feeding behaviors of the whales using the program Trackplot (Ware et al. 2006) and other methods (e.g., Goldbogen et al. 2014).

Overall, this newly established relationship between MERI and WHOI has the potential to greatly increase knowledge of the biology, ecology and behavior of blue whales, as well as of several other marine mammal species, in the Gulf of Corcovado. This work will also yield insights about how blue whales utilize the study area, and will provide information for policy makers regarding how best to protect the unique habitats that exist within the Gulf of Corcovado.

\section{Acknowledgments}

This work was carried out under Chilean research permit PINV 38-2014 Ballena Azul, Golfo Corcovado, from the Ministerio de Economia, Fomento y Turismo, Subsecreteria de Pesca y Acuicultura. Thanks to the captain and crew of the Centinela: Nestor España - captain, Thomas Montt - mate, Nicanor Montaña - engineer, and José Bahamontes - deck crew. Thanks also to Frants Jensen for assistance with analysis of tag data.

\section{References}

Branch, T. A., Abubaker, E. M. N., Mkango, S. and Butterworth, D. S. (2007). Separating southern blue whale subspecies based on length frequencies of sexually mature females. Marine Mammal Science, 23(4), 803-833. doi:10.1111/j.1748-7692.2007.00137.x

Buchan, S. J., Rendell, L. E. and Hucke-Gaete, R. (2010). Preliminary recordings of blue whale (Balaenoptera musculus) vocalizations in the Gulf of Corcovado, northern Patagonia, Chile. Marine Mammal Science, 26: 451-459. doi: 10.1111/j.1748-7692.2009.00338.x 
Buchan, S., Hucke-Gaete, R., Rendell, L. and Stafford, K. (2014). A new song recorded from blue whales in the Corcovado Gulf, Southern Chile, and an acoustic link to the Eastern Tropical Pacific. Endangered Species Research, 23(3), 241-252. doi:10.3354/esr00566

Cummings, W. C., and Thompson, P. O. (1971). Underwater sounds from the blue whale, Balaenoptera musculus. Journal of the Acoustical Society of America 50:1193-1198

Goldbogen, J. A., Calambokidis, J., Friedlaender, A. S., Francis, J., DeRuiter, S. L., Stimpert, A. K., Falcone, E., and Southall, B. L. (2013). Underwater acrobatics by the world's largest predator: $360^{\circ}$ rolling manoeuvres by lunge-feeding blue whales. Biology Letters, 9(1), 20120986

Götz, T., Antunes, R., and Heinrich, S. (2010). Echolocation clicks of free-ranging Chilean dolphins (Cephalorhynchus eutropia). The Journal of the Acoustical Society of America, 128(2), 563-566

Kyhn, L. A., Jensen, F. H., Beedholm, K., Tougaard, J., Hansen, M., and Madsen, P. T. (2010). Echolocation in sympatric Peale's dolphins (Lagenorhynchus australis) and Commerson's dolphins (Cephalorhynchus commersonii) producing narrow-band high-frequency clicks. The Journal of experimental biology, 213(11), 1940-1949

Goldbogen, J. A., Stimpert, A. K., DeRuiter, S. L., Calambokidis, J., Friedlaender, A. S., Schorr, G. S., Moretti, D. J., Tyack, P. L, and Southall, B. L. (2014). Using accelerometers to determine the calling behavior of tagged baleen whales. The Journal of Experimental Biology: jeb-103259

Hucke-Gaete, R. and Buchan, S. (2012). Passive acoustic monitoring of blue whales throughout the Chiloense Ecoregion, Chile. A progress report to the Melimoyu Ecosystem Research Institute

Hucke-Gaete, R., Osman, L. P., Moreno, C. A., Findlay, K. P., and Ljungblad, D. K. (2004). Discovery of a blue whale feeding and nursing ground in southern Chile. Proceedings of the Royal Society of London. Series B: Biological Sciences, 271(Suppl 4), S170-S173

Johnson, M. P., and Tyack, P. L. (2003). A digital acoustic recording tag for measuring the response of wild marine mammals to sound. IEEE Journal of Oceanic Engineering, 28(1), 3-12

Marques, T. A., Thomas, L., Martin, S. W., Mellinger, D. K., Ward, J. A., Moretti, D. J., Harris, D. and Tyack, P. L. (2013). Estimating animal population density using passive acoustics.

Biological Reviews 88: 287-309. doi: 10.1111/brv.12001 
Sayigh, L., Esch, C., Wells, R. and Janik, V. (2007). Facts about bottlenose dolphin signature whistles. Animal Behaviour 74:1631-1642

Torres-Florez, J. P., Hucke-Gaete, R., Rosenbaum, H. and Figueroa, C. C. (2014). High genetic diversity in a small population: the case of Chilean blue whales. Ecology and Evolution, 4(8), 1398-1412. doi:10.1002/ece3.998

Ware, C., Arsenault, R., and Plumlee, M. (2006). Visualizing the underwater behavior of humpback whales. IEEE Computer Graphics and Applications 26(4):14-18

Williams, R., Hedley, S. L., Branch, T. a, Bravington, M. V, Zerbini, A. N. and Findlay, K. P. (2011). Chilean blue whales as a case study to illustrate methods to estimate abundance and evaluate conservation status of rare species. Conservation Biology: The Journal of the Society for Conservation Biology, 25(3), 526-35. doi:10.1111/j.1523-1739.2011.01656.x 


\section{Appendix I \\ Instructions for blue whale behavioral data collection}

Behavioral data should be collected at 3-minute point samples, using a timer that can be set to ring repeatedly at 3 minute intervals.

When the timer goes off, data are collected from the next sighting of the tagged animal. If the tagged animal is not visible within 2 minutes, this will be a "missed point."

As soon as the animal is sighted after the timer goes off, obtain a waypoint from the GPS. This will enable us to synchronize the behavioral, tag and LOGGER data. Next, get a range and magnetic compass bearing to the animal, this will enable reconstruction of whale movements. Then collect remaining categories as outlined below.

Categories on the data sheet (See Figure A1):

1) Time: Real time of observation

2) Wpt: Waypoint number from GPS

3) Range/bearing: estimate range in meters to tagged animal and get a magnetic compass bearing

4) Group size: Number of animals in current group

5) Spread: see categories outlined at bottom of sheet (Figure A1). These will not be relevant if there is only one whale.

6) Synch: see categories at bottom of sheet (Figure A1). These will not be relevant if there is only one animal.

7) Behav: Choose predominant activity for previous 3 minute interval: Travel, Forage, Prob Forage, Rest, Social, Mill, Other/Unknown. If there are others that should be added based on observations, feel free to do so.

8) Activ Level: see categories at bottom of sheet (Figure A1). These are helpful to know if the animal is moving quickly, slowly, etc.

9) NN Dist (BL): This is the distance of the nearest neighbor in body lengths. Not relevant if only one animal is present.

10) NN ID: This is the ID of the nearest neighbor, and would require that animals are distinctive enough to assign descriptive names, such as those seen at the bottom of the sheet for group composition; e.g., AM for adult male, $\mathrm{C}$ for calf (Figure A1). Not relevant if only one animal present

11) Comments: anything else that doesn't fit in the other boxes. This would include relevant photo frame numbers, any information about group geometry, composition, ID's (i.e., 1 adult male, 2 adult females, 2 calves, etc., see codes at bottom of sheet (Figure A1)), whether or not there are other blue whales in the area and how far, whether there are any other species visible and their distance, Beaufort sea state (BSS - affects sighting conditions), and distance, number and type of boats in the area, and any other information that could be relevant or useful. 
Blue Whale Focal Follow

Page___of ___

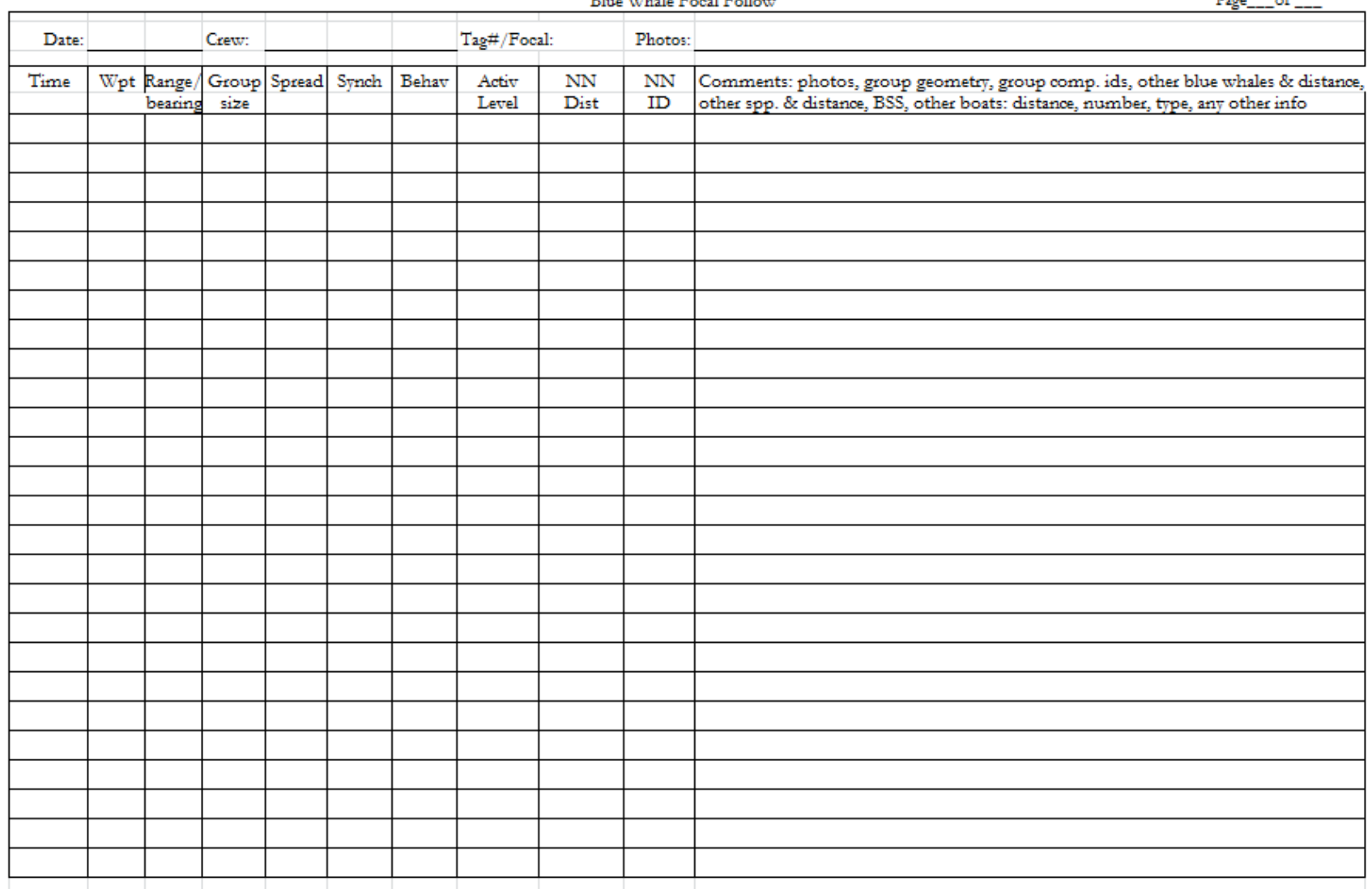

Group spread (score-majority of group):

VT $=<1$ Body Length (very tight)

TI $=1-3 \mathrm{BL}$ ( (tight)

$\mathrm{MO}=3-5 \mathrm{BL} s$ (moderate)

LO $=5-10 \mathrm{BL} s$ (loose)

-if > 10 BLs ["30m): not part of focal group
Synchrony (Bcore-entire group):

H: High: all together @ poin

M: Medium: all surface w/in $30^{\prime \prime}$

L: Low: all don't surface w/ in $30^{\prime \prime}$

Activity: Group composition:

$\mathrm{H}=$ High AM: Adult males

M=Med. AF: Adult females

L=Low AU: Adult-unkn.

J: Juvenile

C: Calves

UN: Unknown

Figure A1: Data sheet for behavioral observations of tagged whales 



\begin{tabular}{|c|c|c|}
\hline $\begin{array}{l}\text { REPORT DOCUMENTATION } \\
\text { PAGE }\end{array}$ & $\begin{array}{ll}\text { 1. REPORT NO. } & \\
\text { WHOI-2014-05 }\end{array}$ & 3. Recipient's Accession No. \\
\hline \multirow{2}{*}{\multicolumn{2}{|c|}{$\begin{array}{l}\text { 4. Title and Subtitle } \\
\text { A Preliminary Investigation into the Ecology and Behavior of Blue Whales } \\
\text { (Balaenoptera musculus) in the Gulf of Corcovado, Chile }\end{array}$}} & $\begin{array}{l}\text { 5. Report Date } \\
\text { September } 2014\end{array}$ \\
\hline & & 6. \\
\hline \multicolumn{2}{|c|}{$\begin{array}{l}\text { 7. Author(sAlessandro Bocconcelli, Leigh Hickmott, Rafaela Landea Briones, Gloria Howes, and } \\
\text { Laela Savigh }\end{array}$} & 8. Performing Organization Rept. No. \\
\hline \multirow{2}{*}{\multicolumn{2}{|c|}{$\begin{array}{l}\text { 9. Performing Organization Name and Address } \\
\text { Woods Hole Oceanographic Institution } \\
\text { Woods Hole, Massachusetts } 02543\end{array}$}} & 10. Project/Task/Work Unit No. \\
\hline & & $\begin{array}{l}\text { 11. Contract(C) or Grant(G) No. } \\
\text { (C) } \\
\text { (G) }\end{array}$ \\
\hline \multirow{3}{*}{\multicolumn{2}{|c|}{$\begin{array}{l}\text { 12. Sponsoring Organization Name and Address } \\
\text { Melimoyu Ecosystem Research Institute (MERI) U.S.A. } \\
\text { P.O. Box } 2428 \\
\text { Edgartown, Massachusetts } 02539\end{array}$}} & 13. Type of Report \& Period Covered \\
\hline & & Technical Report \\
\hline & & 14. \\
\hline
\end{tabular}

15. Supplementary Notes

This report should be cited as: Woods Hole Oceanographic Institution Technical Report, WHOI-2014-05.

\section{Abstract (Limit: 200 words)}

A joint effort between WHOI and the Melimoyu Ecosystem Research Institute (MERI) sought to gain a better understanding of a population of blue whales (Balaenoptera musculus) in the Gulf of Corcovado, Chile. A cruise in March 2014 resulted in the deployment of 5 DTAGs, which are miniature sound and orientation recording tags that are attached via suction cups. A total of five tag deployments on four individual whales were achieved, totaling $21 \mathrm{hr} 11 \mathrm{~min}$. Dives were predominantly between 10 and $50 \mathrm{~m}$ in depth, with a maximum of $139 \mathrm{~m}$. Sloughed skin found on the suction cups of recovered tags and fecal samples were preserved to be used for genetic, dietary and pollutant analyses. Acoustic data on the tags revealed numerous calls from distant blue whales, and an apparent call exchange was recorded between a tagged juvenile whale and a distant animal. Photoidentification images and acoustic recordings of all marine mammal species encountered were obtained whenever possible; these included humpback whales (Megaptera novaeangliae), Pealeâ's dolphins (Lagenorhynchus australis), Chilean dolphins (Cephalorhynchus eutropia), and bottlenose dolphins (Tursiops truncatus). Continuation of this collaboration has great potential to provide information to policy makers regarding how to protect the unique habitats in this region.

17. Document Analysis a. Descriptors

blue whale

Corcovado Bay, Chile

ecology and behavior

b. Identifiers/Open-Ended Terms

c. COSATI Field/Group

18. Availability Statement

Approved for public release; distribution unlimited.

\begin{tabular}{|l|l|}
\hline 19. Security Class (This Report) & $\begin{array}{l}\text { 21. No. of Pages } \\
29\end{array}$ \\
\hline 20. Security Class (This Page) & 22. Price \\
\hline
\end{tabular}

